\title{
Edaphobacter modestus gen. nov., sp. nov., and Edaphobacter aggregans sp. nov., acidobacteria isolated from alpine and forest soils
}

Correspondence
Jörg Overmann
j.overmann@Irz.uni-muenchen.de

\author{
Isabella H. Koch, ${ }^{1}$ Frederic Gich, ${ }^{1}$ Peter F. Dunfield ${ }^{2}$ and Jörg Overmann ${ }^{1}$ \\ ${ }^{1}$ Bereich Mikrobiologie, Ludwig-Maximilians-Universität München, Maria-Ward-Str. 1a, \\ D-80638 München, Germany \\ ${ }^{2}$ Institute of Geological and Nuclear Sciences, Wairakei Research Centre, Wairakei, Private Bag \\ 2000, Taupo, New Zealand
}

The phylum Acidobacteria is currently represented mostly by environmental 16S rRNA gene sequences, and the phylum so far contains only four species with validly published names, Holophaga foetida, Geothrix fermentans, Acidobacterium capsulatum and Terriglobus roseus. In the present study, two novel strains of acidobacteria were isolated. High-throughput enrichments were set up with the MicroDrop technique using an alpine calcareous soil sample and a mixture of polymeric carbon compounds supplemented with signal compounds. This approach yielded a novel, previously unknown acidobacterium, strain $\mathrm{Jbg}-1^{\top}$. The second strain, $\mathrm{Wbg}-1^{\top}$, was recovered from a co-culture with a methanotrophic bacterium established from calcareous forest soil. Both strains represent members of subdivision 1 of the phylum Acidobacteria and are closely related to each other (98.0\% 16S rRNA gene sequence similarity). At a sequence similarity of $93.8-94.7 \%$, strains $\mathrm{Jbg}-1^{\top}$ and $\mathrm{Wbg}-1^{\top}$ are only distantly related to the closest described relative, Terriglobus roseus $\mathrm{KBS} 63^{\top}$, and accordingly are described as members of the novel genus Edaphobacter gen. nov. Based on the DNA-DNA relatedness between strains $\mathrm{Jbg}-1^{\top}$ and $\mathrm{Wbg}-1^{\top}$ of $11.5-13.6 \%$ and their chemotaxonomic and phenotypic characteristics, the two strains are assigned to two separate species, Edaphobacter modestus sp. nov. (the type species), with strain $\mathrm{Jbg}-1^{\top}\left(=\right.$ ATCC BAA $\left.-1329^{\top}=\mathrm{DSM} 18101^{\top}\right)$ as the type strain, and Edaphobacter aggregans sp. nov., with strain $\mathrm{Wbg}^{-1}{ }^{\top}\left(=\mathrm{ATCC}\right.$ BAA $\left.-1497^{\top}=\mathrm{DSM} 19364^{\top}\right)$ as the type strain. The two novel species are adapted to low carbon concentrations and to neutral to slightly acidic conditions.
Based on analyses of 16S rRNA gene clone libraries, members of the phylum Acidobacteria typically represent about $20 \%$ of soil bacterial communities but can contribute up to 50 or even $80 \%$ in some cases (Dunbar et al., 1999; Janssen, 2006; Chan et al., 2006). These culture-independent studies indicate that the diversity of this phylum is nearly as great as the diversity of the phylum Proteobacteria (Ludwig et al., 1997; Hugenholtz et al., 1998). In pronounced contrast to the high overall phylogenetic diversity, only four species, Acidobacterium capsulatum (Kishimoto et al., 1991), Holophaga foetida (Liesack et al., 1994), Geothrix fermentans (Coates et al.,

The GenBank/EMBL/DDBJ accession numbers for the $16 \mathrm{~S}$ rRNA gene sequences of strains $\mathrm{Jbg}^{-1^{\top}}$ and $\mathrm{Wbg}^{-1^{\top}}$ are $\mathrm{D0} 528760$ and D0528761.

Detailed fatty acid compositions and API ZYM results for the novel strains and an extended neighbour-joining tree are available as supplementary material with the online version of this paper.
1999) and Terriglobus roseus (Eichorst et al., 2007), have validly published names to date.

Within the acidobacteria, eight phylogenetic subdivisions were previously recognized (Hugenholtz et al., 1998). Recently, the number of subdivisions was extended to 26 (Barns et al., 2007). G. fermentans and H. foetida are representatives of subdivision 8. G. fermentans is a strictly anaerobic bacterium that oxidizes acetate and other simple organic acids with $\mathrm{Fe}(\mathrm{III})$ as the sole electron acceptor (Coates et al., 1999). H. foetida is a strictly anaerobic, demethylating homoacetogen that degrades aromatic compounds to acetate and is capable of transferring methyl groups from phenylmethylethers to sulfide, thus forming methanethiol and dimethyl sulfide (Bak et al., 1992). A. capsulatum and T. roseus are the sole described representatives of subdivision 1; additional aerobic chemo-organotrophic strains have been isolated, however (Sait et al., 2002; Joseph et al., 2003; Stevenson et al., 2004; Eichorst et al., 2007). In the soil environment, members of subdivisions 1, 4 and 6 are the most abundant groups of 
acidobacteria (Janssen, 2006). However, since A. capsulatum is an acidophile that grows between $\mathrm{pH} 3.0$ and 6.0, its physiology may not be representative of many other acidobacteria. Still, subdivision 1 acidobacteria are more abundant in clone libraries from acidic soils, and members of this subdivision can be selectively cultivated on solid laboratory media at low pH (Sait et al., 2006).

In the present study, two novel strains of acidobacteria were isolated from two different soil types. Both isolates are aerobic chemoheterotrophs, but they are only distantly related phylogenetically to $T$. roseus and A. capsulatum.

One soil sample was obtained from an alpine rendzina (mollisols: rendolls) located at an altitude of $1400 \mathrm{~m}$ on Jochberg (close to Kochel in southern Germany). The upper organic-rich $A_{h}$ horizon extended over a depth of $22 \mathrm{~cm}$. The top $3 \mathrm{~cm}$ were sampled in February 2002 at an in situ temperature of $-3{ }^{\circ} \mathrm{C}$. Most-probable-number cultures were set up in soil solution equivalent (SSE) ( $\mathrm{pH} \mathrm{6.3;}$ Angle et al., 1991) buffered with $10 \mathrm{mM}$ HEPES/ $\mathrm{NaOH}$ at a $\mathrm{pH}$ of 6.3, employing the high-throughput MicroDrop technique (Bruns et al., 2003b). As a carbon source, the medium was supplemented with a polymer mixture (Chin et al., 1999) containing pectin, chitin, soluble starch, cellulose, xylan and curdlan at concentrations of $0.1 \%$ $(\mathrm{w} / \mathrm{v})$ each. The medium was spiked with the inducer molecules cyclic AMP (cAMP), $N$-(oxohexanoyl)-DL-homoserine lactone (OHHL) and $N$-(butyryl)-DL-homoserine lactone (BHL), each at a final concentration of $10 \mu \mathrm{M}$ (Bruns et al., 2003a). Each culture was inoculated with 50 bacterial cells and incubated at $15{ }^{\circ} \mathrm{C}$. Enrichments were screened for the presence of acidobacteria by group-specific PCR after lysis of the cells by six consecutive freeze-thaw cycles, employing primers $31 \mathrm{~F}$ and $341 \mathrm{r}$ and the conditions described previously ( $\mathrm{Zul}$ et al., 2007). One of the positive enrichments was chosen to isolate strain $\mathrm{Jbg}-1^{\mathrm{T}}$ on agarsolidified HD medium (1:10-diluted; $0.05 \%$ casein peptone, $0.01 \%$ glucose, $0.025 \%$ yeast extract, $\mathrm{w} / \mathrm{v}$ ).

The second novel acidobacterium, strain $\mathrm{Wbg}-1^{\mathrm{T}}$, was isolated from a protorendzina (leptosol) in a deciduous forest near Würzburg (Germany). The upper $8-13 \mathrm{~cm}$ of the $A_{h}$ horizon were sampled in July 2001 (Knief et al., 2003) and soil crumbs were placed on agar plates of dilute ammonium mineral salts medium containing (per litre) $0.1 \mathrm{~g} \mathrm{NH}_{4} \mathrm{Cl}, 0.2 \mathrm{~g} \mathrm{MgSO}_{4} .7 \mathrm{H}_{2} \mathrm{O}, 0.04 \mathrm{~g} \mathrm{CaCl}_{2}, 0.001 \mathrm{~g}$ sequestrene $\mathrm{Fe}$ [ethylenediaminedi(o-hydroxyphenylacetic) acid (Fe EDDHA)], $0.1 \mathrm{ml}$ trace elements (Whittenbury et al., 1970) and $10 \mathrm{ml}$ sterile-filtered $100 \mathrm{mM} \mathrm{NaH} \mathrm{PO}_{4} /$ $\mathrm{Na}_{2} \mathrm{HPO}_{4}$ buffer ( $\mathrm{pH}$ 7.0). Incubation at $20{ }^{\circ} \mathrm{C}$ in a gastight chamber containing $20 \%(\mathrm{v} / \mathrm{v})$ methane in air yielded large, slimy, semi-transparent masses composed primarily of the methane-oxidizing proteobacterium Methylocella silvestris (Dunfield et al., 2003) around the soil crumbs on the plates. After several transfers, colonies were streaked on R2A agar (Oxoid) for the isolation of accompanying bacteria. Among the latter, strain $\mathrm{Wbg}-1^{\mathrm{T}}$ was identified as an acidobacterium by $16 \mathrm{~S}$ rRNA gene sequencing.
Strains Jbg- ${ }^{\mathrm{T}}$ and $\mathrm{Wbg}-1^{\mathrm{T}}$ grew on agar-solidified media as well as in liquid media. Similar to other subdivision-1 isolates, strains Jbg- $1^{\mathrm{T}}$ and $\mathrm{Wbg}-1^{\mathrm{T}}$ grew rather slowly, with visible colonies appearing on agar plates only after 2-3 weeks of incubation. Purity of the cultures was checked by phase-contrast microscopy. In addition, 16S rRNA gene fragments were amplified with primers GC357f and 907r and the fragments were subsequently separated by denaturing gradient gel electrophoresis (Muyzer et al., 1997) to check for the presence of additional bacterial phylotypes in the cultures. In all cases, only a single band was detected.

In order to improve the growth rate of the isolates, different media were tested. In comparison to the SSE containing polymeric carbon compounds which was used for isolation of strain $\mathrm{Jbg}-1^{\mathrm{T}}$, the growth rate could be doubled in SSE ( $\mathrm{pH}$ 6.3) supplemented with $0.0025 \%$ yeast extract, $0.1 \%$ glucose and trace element solution SL10 ( $1 \mathrm{ml} \mathrm{l}^{-1}$; Widdel et al., 1983) or in HD medium (1:10-diluted, containing $0.05 \%$ casein peptone, $0.01 \%$ glucose, $0.025 \%$ yeast extract, $\mathrm{pH} 7.0$ ). No growth occurred in undiluted HD medium $(0.5 \%$ casein peptone, $0.1 \%$ glucose, $0.25 \%$ yeast extract), LB medium (Miller; Difco) or Planctomycetes medium (Marine broth 2216; Difco). Therefore, 1:10-diluted HD medium was applied for subsequent growth tests except for the investigation of carbon substrate utilization (see below). A. capsulatum $161^{\mathrm{T}}$ was grown in DSMZ medium 269 (http://www. dsmz.de/microorganisms/media_list.php).

On plates solidified with agar $(1.5 \%, \mathrm{w} / \mathrm{v})$ or gellan gum ( 8 g gellan gum $~^{-1}$; Sigma), strains $\mathrm{Jbg}-1^{\mathrm{T}}$ and $\mathrm{Wbg}-1^{\mathrm{T}}$ formed circular, beige colonies. Colonies of strain Wbg- $1^{\mathrm{T}}$ were highly cohesive. During exponential growth, cells of strain Jbg- $1^{\mathrm{T}}$ were $1.0-1.8 \mu \mathrm{m}$ long and $0.5-0.7 \mu \mathrm{m}$ wide; those of strain $\mathrm{Wbg}-1^{\mathrm{T}}$ were $1.5-2.1 \mu \mathrm{m}$ long and $0.7-$ $0.9 \mu \mathrm{m}$ wide (Fig. 1). Cells of T. roseus KBS $63^{\mathrm{T}}$ and $A$. capsulatum $161^{\mathrm{T}}$ have a similar morphology (Table 1 ). Whereas cells of strain Jbg- $1^{\mathrm{T}}$ were non-motile at neutral $\mathrm{pH}$, the majority of cells were found to be motile in cultures growing below $\mathrm{pH}$ 5.5. In contrast, cells of strain $\mathrm{Wbg}-1^{\mathrm{T}}$ were always non-motile and formed cell aggregates in liquid media. Like T. roseus but unlike A. capsulatum, cells of strains Jbg- $1^{\mathrm{T}}$ and $\mathrm{Wbg}-1^{\mathrm{T}}$ did not form capsules, as tested by negative staining with India ink (Bast, 2001). The presence of poly- $\beta$-hydroxybutyrate (PHB) granules was investigated by epifluorescence microscopy after Nile blue A staining according to Ostle \& Holt (1982). PHB could not be detected in strain $\mathrm{Jbg}-1^{\mathrm{T}}$ or $\mathrm{Wbg}-1^{\mathrm{T}}$ or in $A$. capsulatum $161^{\mathrm{T}}$.

Cells of strains Jbg- $1^{\mathrm{T}}$ and Wbg- $1^{\mathrm{T}}$ stained Gram-negative (Gerhardt et al., 1994), like T. roseus and A. capsulatum. The Gram-negative cell-wall structure was confirmed by transmission electron microscopy of cells harvested in the exponential growth phase (Fig. 2). Cells were fixed with $2.5 \%$ glutardialdehyde in $75 \mathrm{mM}$ cacodylate $/ 2 \mathrm{mM} \mathrm{MgCl}_{2}$ (pH 7.0), post-fixed with $1 \%$ osmium tetroxide buffer and 

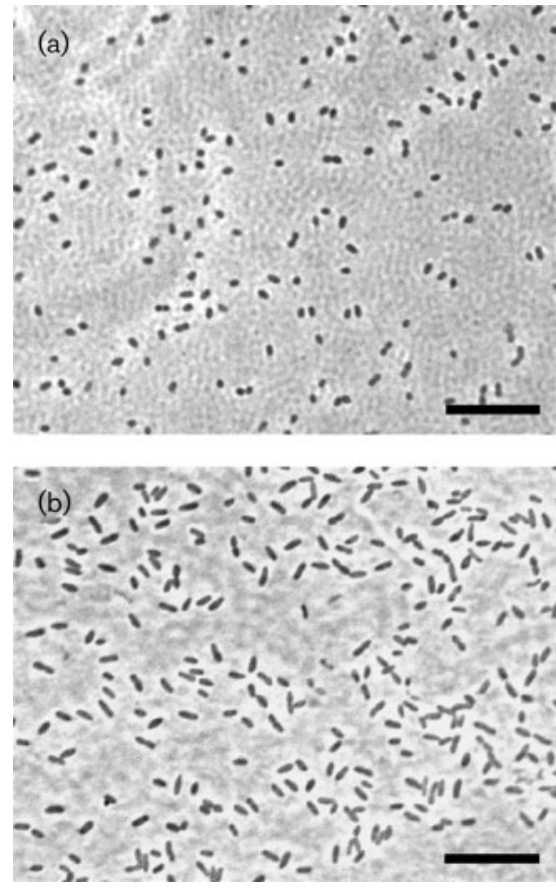

Fig. 1. Phase-contrast photomicrographs of exponentially growing cells of strains $\mathrm{Jbg}^{-1}{ }^{\top}$ (a) and $\mathrm{Wbg}^{-1}{ }^{\top}$ (b). Bars, $10 \mu \mathrm{m}$.

then stained en bloc with uranyl acetate in $20 \%$ acetone. Dehydration was performed with a graded acetone series. Samples were then infiltrated and embedded in Spurr's low-viscosity resin (Spurr, 1969) and ultrathin sections (50 and $70 \mathrm{~nm}$ ) were cut with a diamond knife and mounted on uncoated copper grids. The sections were post-stained with aqueous lead citrate ( $100 \mathrm{mM}, \mathrm{pH} 13.0)$. All micrographs were taken with an EM 912 Zeiss electron microscope equipped with an integrated OMEGA energy filter operated with zero-loss mode. In addition to the structure of the cell envelope, electron microscopy revealed the presence of thin extracellular fibres and tubular structures and an electron-dense centre of the bacterial cells (Fig. 2).

For analysis of the cellular fatty acid composition, strains Jbg- $1^{\mathrm{T}}$ and Wbg- $1^{\mathrm{T}}$ were grown at $25{ }^{\circ} \mathrm{C}$ on agar-solidified HD medium (1:10-diluted), which ensured optimum growth (see above). Forty milligrams (wet weight) of cells was scraped from Petri dishes and fatty acid methyl esters were extracted using the method of Miller (1982) and Kuykendall et al. (1988). Analyses were performed by the Deutsche Sammlung von Mikroorganismen und Zellkulturen (DSMZ). Strain Jbg- $1^{\mathrm{T}}$ contained summed feature $1(16: 1 \omega 7 c$ and $15: 0$ iso $2-\mathrm{OH})$ as the major component (Table 1; see also Supplementary Table S1 in IJSEM Online); 15:0 iso and 16:0 were secondary fatty acids. In the case of strain $\mathrm{Wbg}-1^{\mathrm{T}}, 17: 1 \omega 8 \mathrm{c}$ was the dominant fatty acid, and 16:0 iso and 17:0 were less common. Based on their fatty acid profiles, chemotaxonomic classification of isolates $\mathrm{Jbg}-1^{\mathrm{T}}$ and $\mathrm{Wbg}^{-1^{\mathrm{T}}}$ to a known taxon was not possible. The major fatty acids of $A$. capsulatum $161^{\mathrm{T}}$ are 15:0 iso and 18:169c. Furthermore, the fatty acid profile of the recently described $T$. roseus showed distinct differences, especially from strain $\mathrm{Wbg}-1^{\mathrm{T}}$.

The capacity to utilize different organic carbon substrates was tested in two parallel experiments in SSE ( $\mathrm{pH}$ 6.3) supplemented with $0.0025 \%(\mathrm{w} / \mathrm{v})$ yeast extract and with the trace element solution SL10 $\left(1 \mathrm{ml} \mathrm{l}^{-1}\right)$ and buffered with $10 \mathrm{mM}$ HEPES/NaOH. A spectrum of 104 different carbon sources, comprising organic acids, amino acids, sugars, complex substrates, ketoacids and alcohols, were tested at concentrations between 2.5 and $10 \mathrm{mM}$ (Table 1). Strains Jbg- $1^{\mathrm{T}}$ and $\mathrm{Wbg}-1^{\mathrm{T}}$ as well as A. capsulatum $161^{\mathrm{T}}$ clearly had a greater capacity to use sugars as growth substrates and utilized glucose and lactose as sole carbon and energy sources. The capacity to utilize amino acids was very restricted. Growth substrates specific for strain Jbg- $1^{\mathrm{T}}$ were the sugar lyxose and the sugar alcohols sorbitol, mannitol, myo-inositol, lyxitol and xylitol. Strain Wbg- $1^{\mathrm{T}}$ exhibited the narrowest substrate spectrum (Table 1) but, unlike Jbg- $1^{\mathrm{T}}$ and A. capsulatum $161^{\mathrm{T}}$, utilized aspartate and ornithine. Strains $\mathrm{Jbg}-1^{\mathrm{T}}$ and Wbg- $1^{\mathrm{T}}$ were capable of growing with glutamate and glutamine, in contrast to $A$. capsulatum $161^{\mathrm{T}}$. None of the organic acids and oxo acids tested were utilized. Finally, complex carbon sources such as peptone and Casamino acids promoted growth, albeit only at low concentrations. By their inability to utilize cellobiose, galactose, maltose and mannose, our two isolates can be readily distinguished from $T$. roseus and A. capsulatum. Furthermore, strains $\mathrm{Jbg}-1^{\mathrm{T}}$ and $\mathrm{Wbg}-1^{\mathrm{T}}$ differ from $T$. roseus by their inability to grow on succinate, raffinose or gluconic acid (Table 1).

Catalase and oxidase tests were carried out by standard methods (Gerhardt et al., 1994). Strains Jbg- $1^{\mathrm{T}}$, Wbg- ${ }^{\mathrm{T}}, T$. roseus KBS $63^{\mathrm{T}}$ and A. capsulatum $161^{\mathrm{T}}$ tested positive for catalase, whereas only strain $\mathrm{Jbg}-1^{\mathrm{T}}$ contained a cytochrome $c$ oxidase (Table 1). Anaerobic growth was tested using $1: 10$-diluted HD medium prepared under a nitrogen atmosphere in serum flasks. Before autoclaving, the medium and the headspace were flushed for $10 \mathrm{~min}$ with dinitrogen to replace the air. Nitrate respiration was examined in the same medium by adding $5 \mathrm{mM} \mathrm{KNO}_{3}$ to the serum bottles. These growth experiments indicated that both novel isolates, like T. roseus and A. capsulatum, are obligately aerobic and incapable of nitrate respiration.

Temperature optima for growth were investigated by experiments in $1: 10$-diluted HD medium at between $\mathrm{pH} 3.0$ and 9.0 and temperatures between 4 and $45{ }^{\circ} \mathrm{C}$. Growth was monitored by measuring optical density at $580 \mathrm{~nm}$. Strain Jbg- $1^{\mathrm{T}}$ did not grow above $30{ }^{\circ} \mathrm{C}$, whereas strain Wbg- $1^{\mathrm{T}}$ did not grow above $37^{\circ} \mathrm{C}$. The temperature optimum was $30^{\circ} \mathrm{C}$. Dependence on $\mathrm{pH}$ was determined in media buffered with MES $(\leqslant \mathrm{pH} 6.5)$ or HEPES $(\geqslant \mathrm{pH} 6.5)$. The $\mathrm{pH}$ range for growth was 4.5-7.0 for strain Jbg- $1^{\mathrm{T}}$ and $4.0-7.0$ for strain $\mathrm{Wbg}-1^{\mathrm{T}}$, with optimum growth for both strains at $\mathrm{pH}$ 5.5. Our results are in line 
Table 1. Morphological, biochemical and physiological characteristics of strains $\mathrm{Jbg}-1^{\top}$ and $\mathrm{Wbg}-1^{\top}$ compared with related type strains

Data for A. capsulatum $161^{\mathrm{T}}$ were taken from Kishimoto et al. (1991) and Eichorst et al. (2007) and data for T. roseus KBS $63^{\mathrm{T}}$ were taken from Eichorst et al. (2007). Cell shape and size were determined in HD (1:10-diluted) medium. Cells of all four strains were short, ovoid rods. All strains tested Gram-negative and positive for catalase. If not indicated otherwise, substrates were tested at concentrations of $5 \mathrm{mM}$. $(+)$-D-Glucose was utilized by all four strains. Substrates tested but not utilized for growth by Jbg- $1^{\mathrm{T}}$ and $\mathrm{Wbg}-1^{\mathrm{T}}$ : acetoin $(10 \mathrm{mM}), \mathrm{N}$-acetylglucosamine, adipate, (+)-L-alanine, (-)-D-arabinose, (+)-L-ascorbate, (+)-L-asparagine, benzoate (2 mM), 1,2-butandiol, 2,3-butandiol, butanol, butyrate (2.5 mM), caproate, caprylate, crotonate, (+)-L-cysteine, dulcitol, ethylene glycol, (-)-D-erythrose, erythrulose, (+)-D-fucose, fumarate, glycollate, glyoxylate, heptanoate, $(+)$-L-histidine, $\alpha$-hydroxybutyrate $(2.5 \mathrm{mM}), \beta$-hydroxybutyrate $(2.5 \mathrm{mM}), \gamma$-hydroxybutyrate $(2.5 \mathrm{mM})$, isobutyrate $(2.5 \mathrm{mM}),(+)$-L-isoleucine, isovalerate $(2.5 \mathrm{mM})$, isocitrate, $(+)$-L-leucine, laevulinate, $(+)$-L-lysine, malate, malonate, melezitose, methanol, $(+)$-L-methionine, 2-oxoisocaproate, 2-oxo-D-gluconate, 2-oxoglutarate, 2-oxovalerate, oxaloacetate, $(+)$-L-phenylalanine, $(+)$-L-proline, 1,2propandiol, propanol, propionate, protocatechuate, ribitol, $(+)$-L-serine, L-sorbose, shikimate, tartrate $(2 \mathrm{mM}),(+)$-L-threonine, trimethoxybenzoate $(2 \mathrm{mM}),(+)$-L-tryptophan, $(+)$-L-tyrosine, valerate, $(+)$-L-valine and fermented rumen extract. Substrates tested but not utilized by Jbg- $1^{\mathrm{T}}$, Wbg- $1^{\mathrm{T}}$ and T. roseus KBS $63^{\mathrm{T}}$ : pyruvate, formate and maleic acid. Substrates tested but not utilized by Jbg- $1^{\mathrm{T}}$, Wbg- $1^{\mathrm{T}}$ and $A$. capsulatum $161^{\mathrm{T}}:(+)$-L-arginine, ethanol, glycerol and (+)-L-glycine. Substrates tested but not utilized by all four strains: acetate, citrate and lactate. ND, No data available.

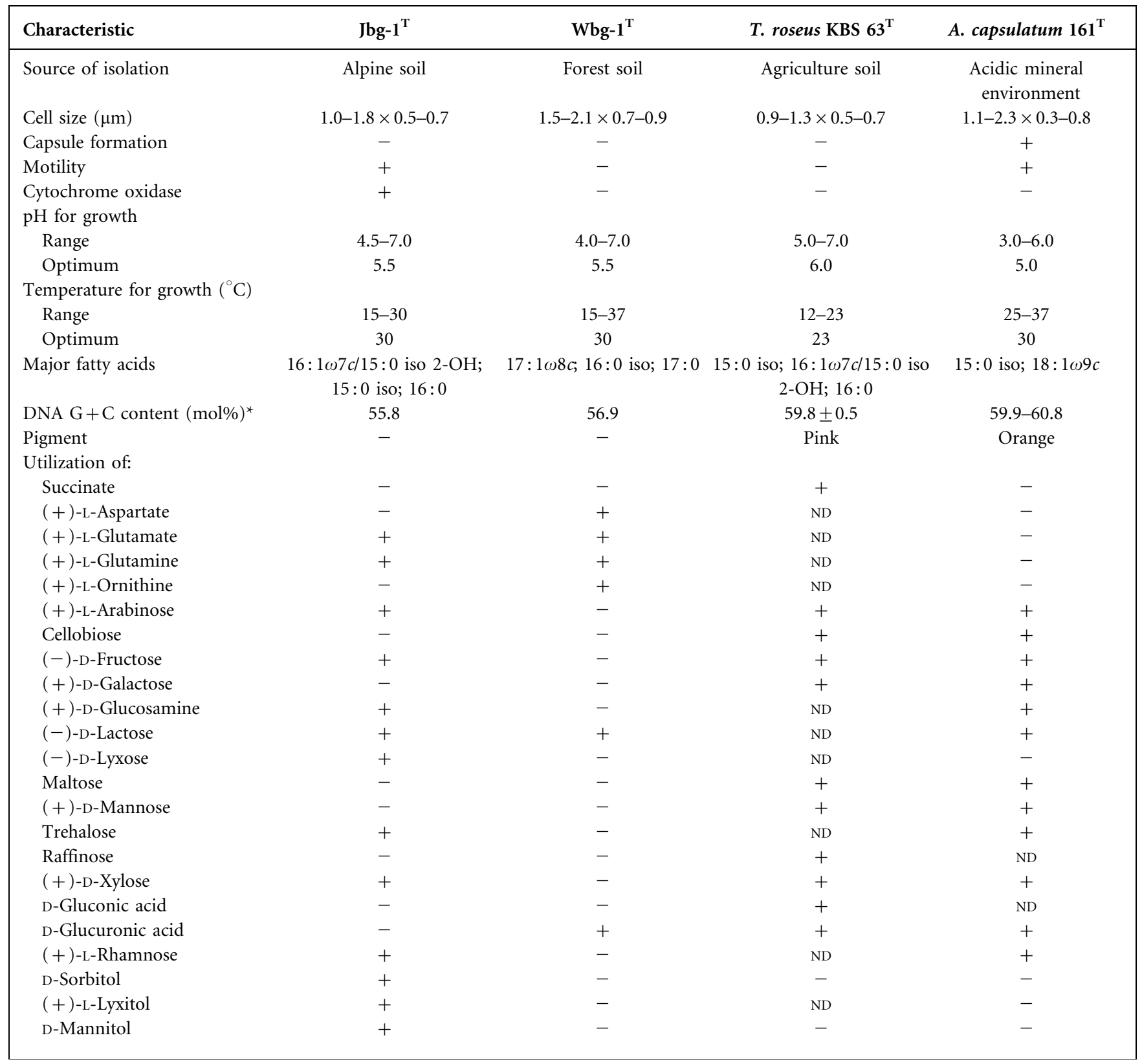


Table 1. cont.

\begin{tabular}{|c|c|c|c|c|}
\hline Characteristic & $\mathrm{Jbg}-\mathbf{1}^{\mathrm{T}}$ & Wbg-1 ${ }^{\mathrm{T}}$ & T. roseus KBS $63^{\mathrm{T}}$ & A. capsulatum $161^{\mathrm{T}}$ \\
\hline myo-Inositol & + & - & ND & - \\
\hline Xylitol & + & - & ND & - \\
\hline Casamino acids $(0.01 \%, \mathrm{w} / \mathrm{v})$ & + & + & ND & + \\
\hline Yeast extract $(0.01 \%, \mathrm{w} / \mathrm{v})$ & + & + & $\mathrm{ND}$ & + \\
\hline Peptone $(0.01 \%, \mathrm{w} / \mathrm{v})$ & + & + & ND & + \\
\hline
\end{tabular}

${ }^{*}$ Values for T. roseus and A. capsulatum represent data for four and eight strains, respectively.
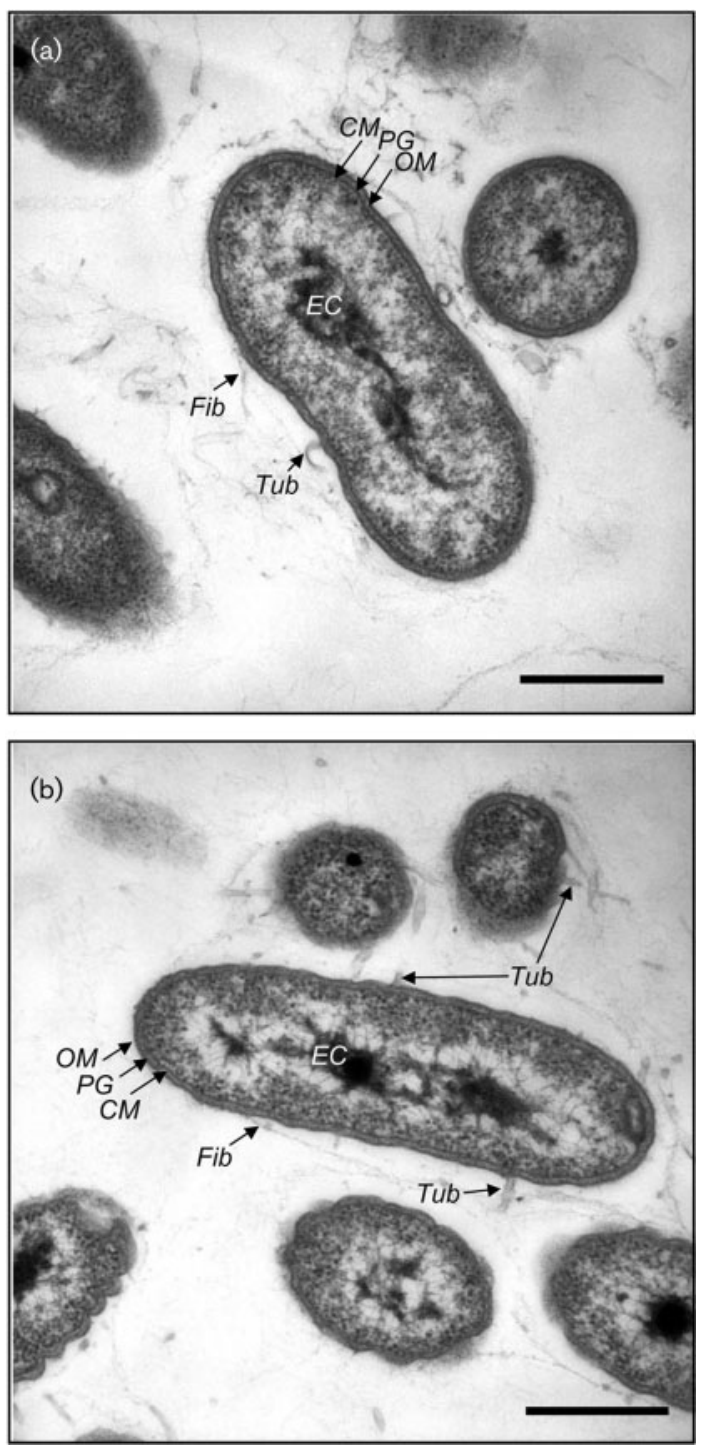

Fig. 2. Electron micrographs of longitudinal and transverse thin sections of cells of strains $\mathrm{Jbg}-1^{\top}$ (a) and $\mathrm{Wbg}^{-1}{ }^{\top}(\mathrm{b})$. The outer membrane (OM), cytoplasmic membrane (CM) and peptidoglycan layer (PG) can be distinguished. In addition, cells bear extracellular tubular structures (Tub), small fibres (Fib) and an electron-dense centre (EC). Bars, $0.5 \mu \mathrm{m}$. with the recent suggestion that moderately acidic $\mathrm{pH}$ may generally favour the growth of members of subdivision 1 of the phylum Acidobacteria (Sait et al., 2002, 2006). In contrast to our present data, however, results of the previous study indicated that other acidobacteria of subdivision 1 exhibit a somewhat lower $\mathrm{pH}$ optimum, between $\mathrm{pH} 4.0$ and 5.0, and an upper limit of growth at $\mathrm{pH}$ 6.5.

We tested the growth of strains $\mathrm{Jbg}-1^{\mathrm{T}}$ and $\mathrm{Wbg}-1^{\mathrm{T}}$ in Hungate tubes under an atmosphere of synthetic air supplemented with $5 \% \mathrm{CO}_{2}$. No difference in growth rates could be observed compared to medium saturated with synthetic air alone, indicating that our isolates do not require elevated partial pressures of $\mathrm{CO}_{2}$.

The activity of 19 different enzymes was tested with API ZYM galleries (bioMérieux) in two replicates (Supplementary Table S2). For comparison, A. capsulatum $161^{\mathrm{T}}$ was tested along with the two new isolates. Whereas earlier studies (Kishimoto et al. 1991) had indicated that $A$. capsulatum $161^{\mathrm{T}}$ contains most of the enzymes tested with the exception of cystyl arylamidase, our API ZYM tests yielded a significantly smaller number of enzyme activities for this strain (Supplementary Table S2). A. capsulatum $161^{\mathrm{T}}$ exhibits acid phosphatase activity but not alkaline phosphatase activity. Strains $\mathrm{Jbg}-1^{\mathrm{T}}$ and $\mathrm{Wbg}-1^{\mathrm{T}}$ possess alkaline phosphatase activity in addition to acid phosphatase activity, which might represent an adaptation to soils with neutral $\mathrm{pH}$. Whereas all three strains tested positive for most glycosidases, cells of strains $\mathrm{Jbg}-1^{\mathrm{T}}$ and $\mathrm{Wbg}-1^{\mathrm{T}}$ synthesize a wider variety of esterases and amidases than does A. capsulatum $161^{\mathrm{T}}$. These include leucyl amidase, valyl amidase and $\alpha$-chymotrypsin (Supplementary Table S2).

The $\mathrm{G}+\mathrm{C}$ content of the genomic DNA was analysed by the DSMZ according to Mesbah et al. (1989). The molecular $\mathrm{G}+\mathrm{C}$ content of genomic DNA of strain Jbg$1^{\mathrm{T}}$ was $55.8 \mathrm{~mol} \%$ and that of strain $\mathrm{Wbg}^{-1}{ }^{\mathrm{T}}$ was $56.9 \mathrm{~mol} \%$. These values are distinctly different from those of four Terriglobus strains $(59.8 \pm 0.5 \mathrm{~mol} \%$ ) (Eichorst et al., 2007) and those of eight strains of A. capsulatum (59.9$60.8 \mathrm{~mol} \%$ ) (Kishimoto et al., 1991) (Table 1).

For phylogenetic classification, the nearly complete $16 \mathrm{~S}$ rRNA genes of strains Jbg- $1^{\mathrm{T}}$ and $\mathrm{Wbg}-1^{\mathrm{T}}$ were sequenced 
after amplification with the primer set $8 \mathrm{f} / 1492 \mathrm{r}$ (Lane, 1991 ) and employing the seven primers $8 \mathrm{f}, 341 \mathrm{f}, 517 \mathrm{r}, 907 \mathrm{r}$, 926f, 1055r and 1492r (Lane, 1991; Amann et al., 1995; Muyzer et al., 1997) for double-pass sequencing. The $16 \mathrm{~S}$ rRNA gene sequences of the closest relatives were retrieved by a BLAST search (Altschul et al., 1997) and the sequences were added to the ARB database (Ludwig et al., 2004), using only sequences longer than $1300 \mathrm{bp}$. The Fast Aligner version 1.03 tool was used for automated alignment. Pairwise phylogenetic distances were calculated using the DNADIST program of the PHYLIP package (Felsenstein, 1989). The resulting alignments were then corrected based on $16 \mathrm{~S}$ rRNA secondary structure information. Positions at which the majority of the sequences contained gaps or uncertainties were filtered out. The final alignment comprised Escherichia coli positions 44-1477, with a total of 1411 valid positions. A phylogenetic tree was constructed using neighbour-joining (Fig. 3) and confirmed using the maximum-likelihood algorithm (Fast DNA_ML; not shown). The two treeing methods yielded similar results. Bootstrap values were calculated from 100 bootstrap resamplings generated with the SEQBOOT and CONSENSE programs of the PHYLIP package.

Numerous 16S rRNA gene sequences of environmental clones of closely related acidobacteria have accumulated in GenBank over recent years, and the isolation of several strains of acidobacteria has been reported (Sait et al., 2002; Joseph et al., 2003; Stevenson et al., 2004; Chan et al., 2006; Eichorst et al., 2007). To date, however, the only species of subdivision 1 of the phylum Acidobacteria with validly published names are the distantly related $A$. capsulatum and, recently, T. roseus (Eichorst et al., 2007). 16S rRNA gene sequence comparisons between strains Jbg- $1^{\mathrm{T}}$, Wbg$1^{\mathrm{T}}$ and the four available strains of $T$. roseus revealed similarities of $93.8-94.7 \%$ (Fig. 3). Sequence similarities of A. capsulatum $161^{\mathrm{T}}$ to strains Jbg- $1^{\mathrm{T}}$ and $\mathrm{Wbg}-\mathrm{1}^{\mathrm{T}}$ are only 91.1 and $92.8 \%$ (Fig. 3). Finally, our analyses demonstrated that strains Jbg- $1^{\mathrm{T}}$ and $\mathrm{Wbg}-\mathrm{1}^{\mathrm{T}}$ are phylogenetically very distantly related to strain Ellin6076 (Fig. 3), tentatively named 'Solibacter usitatus' (http://jgi.doe.gov), with sequence similarities of only $81.7-82.6 \%$. Although the phylogenetic definition of a genus has been a matter of debate (Wayne et al., 1987), a value of $95 \%$ 16S rRNA gene sequence similarity has previously been suggested to delineate different prokaryotic genera (Ludwig et al., 1998). Furthermore, bootstrap support for the separate cluster encompassing strains Jbg- $1^{\mathrm{T}}$ and $\mathrm{Wbg}-1^{\mathrm{T}}$ and three additional sequences was high (Fig. 3; Supplementary Fig. S1). Based on our phylogenetic analysis of all available related environmental clones and isolated strains, our novel isolates represent a distinct lineage which is well separated from members of the genera Terriglobus, Acidobacterium and 'Solibacter' (Supplementary Fig. S1). The phylogenetic distance from strains $\mathrm{Jbg}-1^{\mathrm{T}}$ and $\mathrm{Wbg}-1^{\mathrm{T}}$ to members of the genus Terriglobus is commensurate with the differences in the $\mathrm{G}+\mathrm{C}$ content and substrate utilization patterns. Based on these characteristics (Table 1 and Supplementary
Tables S1 and S2), the two strains $\mathrm{Jbg}-1^{\mathrm{T}}$ and $\mathrm{Wbg}-1^{\mathrm{T}}$ represent a new bacterial genus which is described as Edaphobacter gen. nov. In addition to the two novel isolates, the genus Edaphobacter at present includes the soil isolates Ellin5021 (Joseph et al., 2003) and Ellin337 (Sait et al., 2002) as well as isolate TAA166 from a termite hindgut (Stevenson et al., 2004). Two other sequence clusters are suggested to represent the currently known phylogenetic breadth of the genera Terriglobus and 'Solibacter' (marked in Fig. 3).

According to our analysis, the novel isolates obtained in this study represent members of subdivision 1 of the phylum Acidobacteria. The 16S rRNA gene sequence similarity between isolates $\mathrm{Jbg}-1^{\mathrm{T}}$ and $\mathrm{Wbg}-1^{\mathrm{T}}$ is $98.0 \%$. Based on our phylogenetic analysis (Fig. 3), the other close relatives (Ellin5021, Ellin337 and TAA166) exhibited sequence similarities of $98.6-97.5 \%$ to strains $\mathrm{Jbg}-1^{\mathrm{T}}$ and Wbg- $1^{\mathrm{T}}$, indicating that additional members of the genus Edaphobacter exist not only in soil but also in other environments such as the termite hindgut.

Since the 16S rRNA gene sequence similarity between the two isolates was $98.0 \%$, DNA-DNA hybridization studies were performed in order to determine whether the two isolates should be assigned to one species. DNA was isolated using a French pressure cell (Thermo Spectronic) and purified by chromatography on hydroxyapatite as described by Cashion et al. (1977). DNA-DNA hybridization was carried out as described by De Ley et al. (1970) under consideration of the modifications described by Huß et al. (1983), using a model Cary 100 Bio UV/Vis spectrophotometer equipped with a Peltier-thermostatted $6 \times 6$ multicell changer and a temperature controller with in situ temperature probe (Varian). The DNA-DNA relatedness determined for strains $\mathrm{Jbg}-1^{\mathrm{T}}$ and $\mathrm{Wbg}-1^{\mathrm{T}}$ was $11.5-13.6 \%$. Although the similarity of the $16 \mathrm{~S}$ rRNA gene sequences of strains Jbg- $1^{\mathrm{T}}$ and $\mathrm{Wbg}-1^{\mathrm{T}}$ exceeds the value commonly used for the delineation of a bacterial species $(\geqslant 97 \% 16 \mathrm{~S}$ rRNA gene sequence similarity; Rosselló-Mora \& Amann, 2001), the value of the DNA-DNA relatedness is significantly below the accepted criterion ( $\geqslant 70 \%$; Rosselló-Mora \& Amann, 2001). Similarly, the chemotaxonomic (Supplementary Table S1) and phenotypic (Table 1) characteristics of the two isolated strains differ significantly, supporting the assignment of the two strains to separate species, which are described as Edaphobacter modestus gen. nov., sp. nov. (the type species), with strain $J b g-1^{T}$ as the type strain, and Edaphobacter aggregans sp. nov., with strain Wbg- $1^{\mathrm{T}}$ as the type strain.

\section{Description of Edaphobacter gen. nov.}

Edaphobacter [E.da'pho.bac'ter. Gr. neut. n. edaphos soil; N.L. masc. n. bacter (equivalent of Gr. neut. n. baktron) a short rod; N.L. masc. n. Edaphobacter rod-shaped soil bacterium].

Cells are non-spore-forming, short, ovoid rods that do not form a capsule and stain Gram-negative. One of the known 


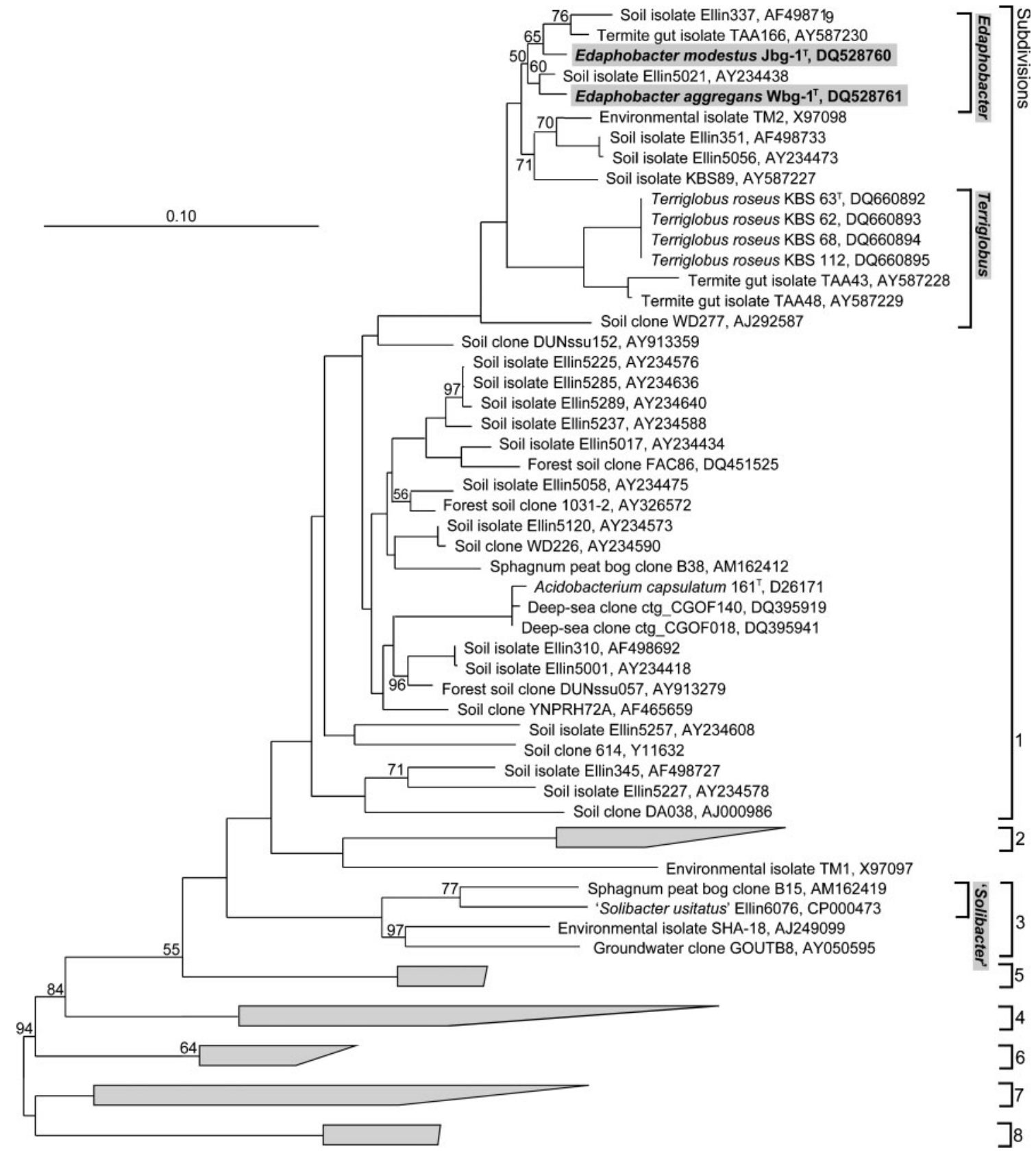

Fig. 3. Affiliation of strains $\mathrm{Jbg}-1^{\top}$ and $\mathrm{Wbg}-1^{\top}$ calculated on the basis of $16 \mathrm{~S}$ rRNA gene sequence information using the neighbour-joining algorithm. Subdivisions of acidobacteria as defined by Hugenholtz et al. (1998) are indicated to the right. For improved clarity, only the most phylogenetically divergent members of each of subdivisions 2-7 are depicted in this tree. Bootstrap values were calculated from 100 bootstrap resamplings; only values $\geqslant 50 \%$ are depicted. Bar, 0.1 fixed-point mutations per nucleotide. A version of this tree including a larger number of related clone sequences is available as Supplementary Fig. S1.

strains is motile at $\leqslant \mathrm{pH}$ 5.5. Cells multiply by binary fission and form circular, beige colonies on agar plates. Do not form PHB granules. Catalase-positive. Fermentation or anaerobic growth with nitrate are not detected. Typical growth substrates are glucose, lactose, glutamate and glutamine. Grow well in media containing $0.05 \%$ casein peptone, $0.01 \%$ glucose and $0.025 \%$ yeast extract. 16S rRNA gene sequence information places the genus within subgroup 1 of the acidobacteria. The $\mathrm{G}+\mathrm{C}$ content of the genomic DNA is $55.8-56.9 \mathrm{~mol} \%$ (determined by HPLC). Occur typically in soils, but also in other environments such as termite hindgut microbial communities. The type species is Edaphobacter modestus. 


\section{Description of Edaphobacter modestus sp. nov.}

Edaphobacter modestus (mo.des'tus. L. masc. adj. modestus moderate, used to refer to the adaptation of the type strain to low substrate concentrations).

Rods are $1.0-1.8 \mu \mathrm{m}$ long and $0.5-0.7 \mu \mathrm{m}$ wide. General characteristics are those given in the genus description. Additional growth substrates are sugars such as arabinose, fructose, rhamnose, lyxose, xylose, trehalose and glucosamine and the sugar alcohols sorbitol, lyxitol, mannitol, myo-inositol and xylitol. Does not use organic acids for growth. Cells exhibit enzyme activities for alkaline and acid phosphatase, naphthol-AS-BI-phosphohydrolase, esterases (C4 and C8), leucyl and valyl arylamidases, $\alpha$-chymotrypsin, $\alpha$ - and $\beta$-glucosidase and $\alpha$ - and $\beta$-galactosidase. Oxidase-positive. Optimum conditions for growth are $30{ }^{\circ} \mathrm{C}$ and $\mathrm{pH}$ 5.5. Major cellular fatty acids are summed feature $1(16: 1 \omega 7 c$ and/or $15: 0$ iso $2-\mathrm{OH})$ and $15: 0$ iso. The $\mathrm{G}+\mathrm{C}$ content of the genomic DNA of the type strain is $55.8 \mathrm{~mol} \%$ (determined by HPLC).

The type strain is $\mathrm{Jbg}-1^{\mathrm{T}}\left(=\mathrm{ATCC}\right.$ BAA $-1329^{\mathrm{T}}=\mathrm{DSM}$ $18101^{\mathrm{T}}$ ), which was isolated from an alpine rendzina near Kochel, southern Bavaria, Germany.

\section{Description of Edaphobacter aggregans sp. nov.}

Edaphobacter aggregans (ag' gre.gans. L. v. aggregare to flock or band together; L. pres. part. aggregans assembling, aggregating).

Rods are 1.5-2.1 $\mu \mathrm{m}$ long and $0.7-0.9 \mu \mathrm{m}$ wide. General characteristics are those given in the genus description. Additional growth substrates are aspartate, ornithine and glucuronic acid. Does not grow on arabinose, fructose, rhamnose, lyxose, xylose, trehalose, glucosamine, sorbitol, lyxitol, mannitol, myo-inositol or xylitol or organic acids. The type strain grows in co-culture with the methaneoxidizing proteobacterium Methylocella silvestris. Cells exhibit enzyme activities for alkaline and acid phosphatase, naphthol-AS-BI-phosphohydrolase, esterases (C4 and C8), leucyl and valyl arylamidases, $\alpha$-chymotrypsin, $\alpha$ - and $\beta$ glucosidase and $\alpha$ - and $\beta$-galactosidase. Oxidase-negative. Optimum conditions for growth are $30{ }^{\circ} \mathrm{C}$ and $\mathrm{pH}$ 5.5. Major cellular fatty acids are $17: 1 \omega 8 c$ and 16:0 iso. The $\mathrm{G}+\mathrm{C}$ content of the genomic DNA of the type strain is $56.9 \mathrm{~mol} \%$ (determined by HPLC).

The type strain is $\mathrm{Wbg}^{-1^{\mathrm{T}}}\left(=\mathrm{ATCC}\right.$ BAA- $1497^{\mathrm{T}}=\mathrm{DSM}$ $19364^{\mathrm{T}}$ ), which was isolated from a protorendzina in a deciduous forest near Würzburg, northern Bavaria, Germany.

\section{Acknowledgements}

This work was supported by a grant of the BMBF (Bundesministerium für Bildung, Wissenschaft, Forschung und Technologie) to J. O. (Biolog/01LC0021). Gerhard Wanner (Bereich Botanik, Ludwig-Maximilians-Universität München) is acknowledged for help with transmission electron microscopy images and
Karin Schubert for help with the deposition of bacterial cultures. DNA-DNA hybridization values were determined by the Identification Services of the DSMZ.

\section{References}

Altschul, S. F., Madden, T. L., Schäffer, A. A., Zhang, J., Zhang, Z., Miller, W. \& Lipman, D. J. (1997). Gapped BLAST and PSI-BLAST: a new generation of protein database search programs. Nucleic Acids Res 25, 3389-3402.

Amann, R. I., Ludwig, W. \& Schleifer, K.-H. (1995). Phylogenetic identification and in situ detection of individual microbial cells without cultivation. Microbiol Rev 59, 143-169.

Angle, J. S., McGrath, S. P. \& Chaney, R. L. (1991). New culture medium containing ionic concentrations of nutrients similar to concentrations found in the soil solution. Appl Environ Microbiol 57, 3674-3676.

Bak, F., Finster, K. \& Rothfuß, F. (1992). Formation of dimethylsulfide and methanethiol from methoxylated aromatic compounds and inorganic sulfide by newly isolated anaerobic bacteria. Arch Microbiol 157, 529-534.

Barns, S. M., Takala, S. L. \& Kuske, C. L. (1999). Wide distribution and diversity of members of the bacterial kingdom Acidobacterium in the environment. Appl Environ Microbiol 65, 1731-1737.

Barns, S. M., Cain, E. C., Sommerville, L. \& Kuske, C. L. (2007). Acidobacteria phylum sequences in uranium-contaminated subsurface sediments expand the known diversity within the phylum. Appl Environ Microbiol 73, 3113-3116.

Bast, E. (2001). Lichtmikroskopische Untersuchung von Mikroorganismen. In Mikrobiologische Methoden, 2nd edn, pp. 203-263. Edited by E. Bast. Heidelberg, Berlin: Spektrum (in German).

Bruns, A., Nübel, U., Cypionka, H. \& Overmann, J. (2003a). Effect of signal compounds and incubation conditions on the culturability of freshwater bacterioplankton. Appl Environ Microbiol 69, 1980-1989.

Bruns, A., Hoffelner, H. \& Overmann, J. (2003b). A novel approach for high throughput assays and the isolation of planktonic bacteria. FEMS Microbiol Ecol 45, 161-171.

Cashion, P., Holder-Franklin, M. A., McCully, J. \& Franklin, M. (1977). A rapid method for the base ratio determination of bacterial DNA. Anal Biochem 81, 461-466.

Chan, O. C., Yang, X., Fu, Y., Feng, Z., Sha, L., Casper, P. \& Zou, X. (2006). 16S rRNA gene analyses of bacterial community structures in the soils of evergreen broad-leaved forests in south-west China. FEMS Microbiol Ecol 58, 247-259.

Chin, K.-J., Hahn, D., Hengstmann, U., Liesack, W. \& Janssen, P. H. (1999). Characterization and identification of numerically abundant culturable bacteria from the anoxic bulk soil of rice paddy microcosms. Appl Environ Microbiol 65, 5042-5049.

Coates, J. D., Ellis, D. J., Gaw, C. V. \& Lovley, D. R. (1999). Geothrix fermentans gen. nov., sp. nov., a novel Fe(III)-reducing bacterium from a hydrocarbon-contaminated aquifer. Int J Syst Bacteriol 49, 1615-1622.

De Ley, J., Cattoir, H. \& Reynaerts, A. (1970). The quantitative measurement of DNA hybridization from renaturation rates. Eur $J$ Biochem 12, 133-142.

Dunbar, J., Takala, S., Barns, S. M., Davis, J. A. \& Kuske, C. R. (1999). Levels of bacterial community diversity in four arid soils compared by cultivation and 16S rRNA gene cloning. Appl Environ Microbiol 65, 1662-1669.

Dunfield, P. F., Khmelenina, V. N., Suzina, N. E., Trotsenko, Y. A. \& Dedysh, S. N. (2003). Methylocella silvestris sp. nov., a novel 
methanotrophic bacterium isolated from an acidic forest cambisol. Int J Syst Evol Microbiol 53, 1231-1239.

Eichorst, S. A., Breznak, J. A. \& Schmidt, T. M. (2007). Isolation and characterization of bacteria from soil that define Terriglobus gen. nov., in the phylum Acidobacteria. Appl Environ Microbiol 73, 2708-2717.

Felsenstein, J. (1989). PHYLIP - phylogeny inference package (version 3.2). Cladistics 5, 164-166.

Gerhardt, P., Murray, R. G. E., Wood, W. A. \& Krieg, N. R. (editors) (1994). Methods for General and Molecular Bacteriology. Washington, DC: American Society for Microbiology.

Hugenholtz, P., Goebel, B. M. \& Pace, N. R. (1998). Impact of culture-independent studies on the emerging phylogenetic view of bacterial diversity. J Bacteriol 180, 4765-4774.

Huß, V. A. R., Festl, H. \& Schleifer, K. H. (1983). Studies on the spectrophotometric determination of DNA hybridization from renaturation rates. Syst Appl Microbiol 4, 184-192.

Janssen, P. H. (2006). Identifying the dominant soil bacterial taxa in libraries of 16S rRNA and 16S rRNA genes. Appl Environ Microbiol 72, 1719-1728.

Joseph, S. J., Hugenholtz, P., Sangwan, P., Osborne, C. A. \& Janssen, P. H. (2003). Laboratory cultivation of widespread and previously uncultured soil bacteria. Appl Environ Microbiol 69, 7210-7215.

Kishimoto, N., Kosako, Y. \& Tano, T. (1991). Acidobacterium capsulatum gen. nov., sp. nov.: an acidophilic chemoorganotrophic bacterium containing menaquinone from acidic mineral environment. Curr Microbiol 22, 1-7.

Knief, C., Lipski, A. \& Dunfield, P. F. (2003). Diversity and activity of methanotrophic bacteria in different upland soils. Appl Environ Microbiol 69, 6703-6714.

Kuykendall, L. D., Roy, M. A., O'Neill, J. J. \& Devine, T. E. (1988). Fatty acids, antibiotic resistance, and deoxyribonucleic acid homology groups of Bradyrhizobium japonicum. Int J Syst Bacteriol 38, 358-361.

Lane, D. J. (1991). 16S/23S rRNA sequencing. In Nucleic Acid Techniques in Bacterial Systematics, pp. 115-175. Edited by E. Stackebrandt \& M. Goodfellow. Chichester: Wiley.

Liesack, W., Bak, F., Kreft, J. U. \& Stackebrandt, E. (1994). Holophaga foetida gen. nov., sp. nov., a new homoacetogenic bacterium degrading methoxylated aromatic compounds. Arch Microbiol 162, 85-90.

Ludwig, W., Bauer, S. H., Bauer, M., Held, I., Kirchhof, G., Schulze, R., Huber, I., Spring, S., Hartmann, A. \& Schleifer, K.-H. (1997). Detection and in situ identification of a widely distributed new bacterial phylum. FEMS Microbiol Lett 153, 181-190.

Ludwig, W., Strunk, O., Klugbauer, S., Klugbauer, N., Weizenegger, M., Neumaier, J., Bachleitner, M. \& Schleifer, K.-H. (1998). Bacterial phylogeny based on comparative sequence analysis. Electrophoresis 19, 554-568.
Ludwig, W., Strunk, O., Westram, R., Richter, L., Meier, H., Yadhukumar, Buchner, A., Lai, T., Steppi, S. \& other authors (2004). ARB: a software environment for sequence data. Nucleic Acids Res 32, 1363-1371.

Mesbah, M., Premachandran, U. \& Whitman, W. B. (1989). Precise measurement of the $\mathrm{G}+\mathrm{C}$ content of deoxyribonucleic acid by highperformance liquid chromatography. Int J Syst Bacteriol 39, 159-167.

Miller, L. T. (1982). Single derivatization method for routine analysis of bacterial whole-cell fatty acid methyl esters, including hydroxy acids. J Clin Microbiol 16, 584-586.

Muyzer, G., Brinkhoff, T., Nübel, U., Santegoeds, C., Schäfer, H. \& Wawer, C. (1997). Denaturing gradient gel electrophoresis (DGGE) in microbial ecology. In Molecular Microbial Ecology Manual, vol. 3.4.4, pp. 1-27. Edited by A. D. L. Akkermans, J. D. van Elsas \& F. J. de Bruijn. Dordrecht: Kluwer Academic.

Ostle, A. G. \& Holt, J. G. (1982). Nile blue A as a fluorescent stain for poly- $\beta$-hydroxybutyrate. Appl Environ Microbiol 44, 238-241.

Rosselló-Mora, R. \& Amann, R. (2001). The species concept for prokaryotes. FEMS Microbiol Rev 25, 39-67.

Sait, M., Hugenholtz, P. \& Janssen, P. H. (2002). Cultivation of globally distributed soil bacteria from phylogenetic lineages previously only detected in cultivation-independent surveys. Environ Microbiol 4, 654-666.

Sait, M., Davis, K. E. R. \& Janssen, P. H. (2006). Effect of pH on isolation and distribution of members of subdivision 1 of the phylum Acidobacteria occurring in soil. Appl Environ Microbiol 72, 1852-1857.

Spurr, A. R. (1969). A low-viscosity epoxy resin embedding medium for electron microscopy. J Ultrastruct Res 26, 31-43.

Stevenson, B. S., Eichorst, S. A., Wertz, J. T., Schmidt, T. M. \& Breznak, J. A. (2004). New strategies for cultivation and detection of previously uncultured microbes. Appl Environ Microbiol 70, $4748-4755$.

Wayne, L. G., Brenner, D. J., Colwell, R. R., Grimont, P. A. D., Kandler, O., Krichevsky, M. I., Moore, L. H., Moore, W. E. C., Murray, R. G. E. \& other authors (1987). International Committee on Systematic Bacteriology. Report of the ad hoc committee on reconciliation of approaches to bacterial systematics. Int J Syst Bacteriol 37, 463-464.

Whittenbury, R., Phillips, K. C. \& Wilkinson, J. F. (1970). Enrichment, isolation and some properties of methane-utilizing bacteria. J Gen Microbiol 61, 205-218.

Widdel, F., Kohring, G.-W. \& Mayer, F. (1983). Studies on dissimilatory sulfate-reducing bacteria that decompose fatty acids. III. Characterization of the filamentous gliding Desulfonema limicola gen. nov. sp. nov., and Desulfonema magnum sp. nov. Arch Microbiol 134, 286-294.

Zul, D., Denzel, S., Kotz, A. \& Overmann, J. (2007). Effects of plant biomass, plant diversity, and water content on bacterial communities in soil lysimeters: implications for the determinants of bacterial diversity. Appl Environ Microbiol 73, 6916-6929. 